\title{
Calcium Binding and Release by Bovine Adrenal Medullary Granules: Relation to Release of Catecholamine from the Granules
}

\author{
Futoshi IzUMI, Takeshi Kashimoto, Akihiko WADA and Motoo OKA* \\ Department of Pharmacology, School of Medicine, University of Occupational and Environmental \\ Health, Kitakyushu 807, Japan \\ *Department of Pharmacology, Tokushima University School of Medicine, Tokushima 770, Japan
}

Abstract: Dynamic aspects of calcium action in the release of catecholamine were investigated in vitro, using perfused bovine adrenal glands and isolated chromaffin granules. The ${ }^{45} \mathrm{Ca}$ which intruded into the chromaffin cells by acetylcholine stimulation was condensed in chromaffin granules and its localization was confined to the stroma of granules. The ${ }^{45} \mathrm{Ca}$ added to isolated granule suspension in the presence of $\mathrm{ATP}-\mathrm{Mg}^{++}$also showed preferential binding to the stroma and this calcium showed a rapid exchange with unlabeled calcium in the medium.

Release of catecholamine from the chromaffin granules was observed in parallel with the binding of calcium to the stroma. Thus, stromal calcium plays an important role in the release of catecholamines.

The transient increase in free calcium concentration evoked by acetylcholine may trigger an increase of stromal calcium turnover. Under such a situation, the granules are brought to an activated, easily releasable state which would be the primary step in catecholamine secretion from the adrenal medullary cells.

Key words: adrenal medulla, chromaffin cells, catecholamine release, calcium ion.

(Received 13 April 1979)

\section{Introduction}

The release of catecholamine from the adrenal medulla on stimulation with acetylcholine is dependent on the existence of extracellular calcium ions (Douglas \& Rubin, 1961). The entry of the calcium ion into the cell is known to be essential for the release of catecholamine (Douglas \& Poisner, 1962). However, despite the central importance of calcium ion in stimulus-secretion coupling, few efforts have been made to define its locus of action in chromaffin cells. Borowitz (1969) found in perfused adrenal glands that influxed ${ }^{45} \mathrm{Ca}$ was condensed mainly in the particulate fraction containing chromaffin granules without net increase of total calcium in this fraction. He indicated that the exchange of calcium in heavy chromaffin granules with calcium in the environment increased during stimulation of adrenal medulla with acetylcholine. Kostron et al. (1977) incubated in vitro partly purified chromaffin granules with ${ }^{45} \mathrm{Ca}$ and character- 
ized the uptake of ${ }^{45} \mathrm{Ca}$ to the granules. The uptake of ${ }^{45} \mathrm{Ca}$ was strongly dependent on temperature, but was not activated by ATP and the ${ }^{45} \mathrm{Ca}$ taken up to the granules localized in the soluble part of granules.

Therefore, it would be agreed that chromaffin granules are one of the calcium receptive sites in chromaffin cells. But it is certainly striking how few experiments have been made to correlate calcium binding with the release of catecholamine from isolated chromaffin granules, since these two processes were not studied simultaneously.

We reported previously that the release of catecholamine from isolated chromaffin granules was stimulated by ATP- $\mathrm{Mg}^{++}$(Oka et al., 1971) and that it also required a low concentration of calcium (Izumi, et al., 1971; Oka, et al., 1972). In this paper, we report the binding of calcium to isolated chromaffin granules and its correlate to the release of catecholamine.

\section{Materials and Method}

\section{Influx of ${ }^{45} \mathrm{Ca}$ and its subcellular distribution}

Bovine adrenal glands were used throughout and were perfused in the reverse direction to blood flow, i.e., through the adrenal vein. The modified Locke's solution used had the following composition (mM): $\mathrm{NaCl}, 154 ; \mathrm{KCl}, 5.6 ; \mathrm{CaCl}_{2}, 2.2 ; \mathrm{MgSO}_{4}, 1.6 ;$ glucose, 10 ; and Tris $-\mathrm{HCl}, 25$ ( $\mathrm{pH} 7.4) . \quad{ }^{45} \mathrm{Ca}$ of high specific activity $(11.3 \mathrm{mCi} / \mathrm{mg}$ ) was added to perfusion fluid to give $1.1 \times 10^{5} \mathrm{dpm} / \mathrm{ml}\left({ }^{45} \mathrm{Ca}\right.$ Locke's solution) without changing the total calcium concentration appreciably. The adrenal glands were first perfused with unlabeled Locke's solution for $30 \mathrm{~min}$ at $37^{\circ} \mathrm{C}$ to washout the blood and achieve a constant flow rate $(4 \mathrm{ml} / \mathrm{min})$. Then they were perfused with ${ }^{45} \mathrm{Ca}$ Locke's for $30 \mathrm{~min}$ and during this period, three $1 \mathrm{ml}$ doses of acetylcholine chloride $\left(2 \times 10^{-5} \mathrm{~g} / \mathrm{ml}\right)$ were injected into the perfusion fluid at intervals of $10 \mathrm{~min}$. Then the adrenal glands were placed in an ice-cold Petri dish and the medullary tissue was carefully excised. The tissue was homogenized in 10 volumes of $0.32 \mathrm{M}$ sucrose containing $40 \mathrm{mM}$ Tris ( $\mathrm{pH} \mathrm{7.4).} \mathrm{The}$ homogenate was fractionated by differential centrifugation into debris, nuclei $(1,000 \times \mathrm{g}$, $10 \mathrm{~min})$, particulate fraction $(10,000 \times \mathrm{g}, 20 \mathrm{~min})$, microsome $(105,000 \times \mathrm{g}, 1 \mathrm{~h})$ and cytoplasmic fraction. The catecholamine content of each fraction was estimated by ethylenediamine condensation method (Weil-Malherbe, 1952). Endogenous calcium was estimated by the atom absorption method after digestion of the material with perchloric acid and nitric acid in the presence of lanthane chloride. ${ }^{45} \mathrm{Ca}$ was extracted with $0.4 \mathrm{~N}$ perchloric acid and its radioactivity was counted in a liquid scintillation counter. Protein was estimated by the Lowry method (Lowry et al., 1951).

\section{Uptake of ${ }^{45} \mathrm{Ca}$ by isolated chromaffin granules and release of catecholamine}

Chromaffin granules were isolated from bovine adrenal medulla by the millipore filter technique, as reported previously (Oka et al., 1966). The standard incubation mixture 
for measuring ${ }^{45} \mathrm{Ca}$ binding and release of catecholamine consisted of $150 \mathrm{mM} \mathrm{KCl}, 4 \mathrm{mM}$ ATP, $2 \mathrm{mM} \mathrm{MgSO}$, $40 \mathrm{mM}$ Tris (pH 7.4) and ${ }^{45} \mathrm{CaCl}_{2} 0.1 \mathrm{mM}$ (diluted with unlabeled $\mathrm{CaCl}_{2}, 2.2 \times 10^{4} \mathrm{dpm} / \mathrm{ml}$ ) in a final volume of $4.0 \mathrm{ml}$. The reaction was started by adding the granules suspended in a solution of $150 \mathrm{mM} \mathrm{KCl}$ and $40 \mathrm{mM}$ of Tris (pH 7.4). The reaction was carried out in centrifuge tubes and after incubation the tubes were cooled in an ice bath and centrifuged at $20,000 \times \mathrm{g}$ for $10 \mathrm{~min}$ at below $4{ }^{\circ} \mathrm{C} .{ }^{45} \mathrm{Ca}$ bound to the granules was extracted from the precipitate with $0.4 \mathrm{~N}$ perchloric acid. Catecholamine in the supernatant was measured simultaneouly to know the amount of catecholamine released during incubation periods.

\section{Results}

\section{Subcellular distribution of ${ }^{45} \mathrm{Ca}$ in adrenal medulla}

When adrenal glands were perfused with Locke's solution containing ${ }^{45} \mathrm{Ca}$ and stimulated by acetylcholine, the ${ }^{45} \mathrm{Ca}$ entered into the cells (data not shown). On fractionation of the glands, the intracellular ${ }^{45} \mathrm{Ca}$ was mainly found in the particulate fraction with high contents of chromaffin granules. The distribution of ${ }^{45} \mathrm{Ca}$ was the same as that of endogenous calcium in the adrenal medulla. On the contrary, magnesium, the other main divalent cation, was mainly found in the cytoplasmic fraction. ${ }^{45} \mathrm{Ca}$ added to the homogenate from control gland also showed similar distribution.

Next, we obtained the particulate fraction and incubated it with ${ }^{45} \mathrm{Ca}$ in $150 \mathrm{mM} \mathrm{KCl}$ or $0.32 \mathrm{M}$ of sucrose. Part of the mixture was centrifuged $(20,000 \times \mathrm{g}, 10 \mathrm{~min}) \mathrm{im}$ mediately getting the total calcium binding to this fraction. The other part of the mixture was layed over $1.8 \mathrm{M}$ of sucrose and centrifuged $(105,000 \times \mathrm{g}, 1 \mathrm{~h})$ getting the calcium binding to the chromaffin granules, since only the chromaffin granules are sedimented in this high density of sucrose and other cell organella such as mitochondria and lysosomes are not. More than $70 \%$ of ${ }^{45} \mathrm{Ca}$ bound to the particulate fraction was recovered in the pellet, showing that this amount of ${ }^{45} \mathrm{Ca}$ was bound to the chromaffin granules. Therefore, it is clear that the chromaffin granules are the main calcium

Table 1. Subcellular distribution of influxed ${ }^{45} \mathrm{Ca}$

\begin{tabular}{lccccc}
\multicolumn{1}{c}{ Fractions } & $\begin{array}{c}\text { Influxed } \\
{ }_{45} \mathrm{Ca}\end{array}$ & Calcium & Magnesium & Catecholamine & Protein \\
\hline Nuclei, Debris & 23.3 & 20.3 & 18.8 & 12.2 & 18.5 \\
Particulate & 62.6 & 67.9 & 20.6 & 57.9 & 28.9 \\
Microsome & 8.0 & 9.2 & 8.1 & 5.6 & 10.0 \\
Cytoplasmic & 6.1 & 2.6 & 52.5 & 24.3 & 42.6 \\
\hline
\end{tabular}

Values are the mean average from 5 experiments expressed as \% distribution. 100\%: ${ }^{45} \mathrm{Ca}, 8.1 \times 10^{5} \mathrm{dpm}$; Calcium, $1.017 \mathrm{mg}$; Magnesium, $1.340 \mathrm{mg}$; Catecholamine, 75. $3 \mathrm{mg}$; Protein, $969.0 \mathrm{mg}$. 


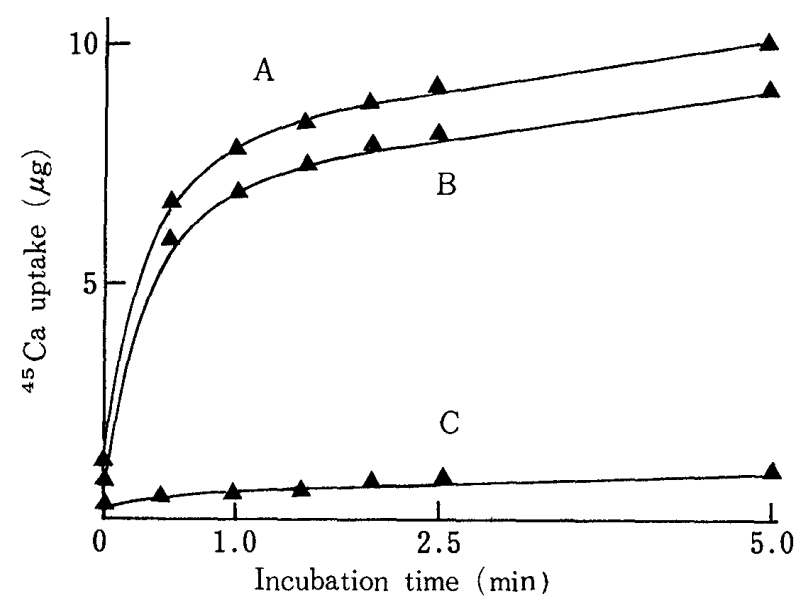

Fig. 1. Binding of ${ }^{45} \mathrm{Ca}$ to chromaffin granules.

Chromaffin granules ( $1500 \mu \mathrm{g}$ of catecholamine) were incubated with $0.1 \mathrm{mM}{ }^{45} \mathrm{Ca}(16$ $\mu \mathrm{g}$ of ${ }^{45} \mathrm{Ca}$ in $4 \mathrm{ml}$ of medium, $2 \times 10^{5} \mathrm{dpm} / \mathrm{ml}$ ) in standard incubation mixture.

Granules were precipitated by centrifugation and then lysed in hypotonic solution (40 $\mathrm{mM}$ Tris, $4 \mathrm{mM}$ ATP and $2 \mathrm{mM} \mathrm{MgSO}_{4}$ ) at $0^{\circ} \mathrm{C}$ and separated into stroma and soluble content. A: Whole granule; B: Stroma; C: Soluble content.

receptive site in chromaffin cells. When granules were incubated with ${ }^{45} \mathrm{Ca}$ in a sucrose medium, the binding of ${ }^{45} \mathrm{Ca}$ was much diminished.

\section{Bindings of ${ }^{45} \mathrm{Ca}$ to isolated chromaffin granules}

Chromaffin granules isolated by millipore filter were incubated with ${ }^{45} \mathrm{Ca}$ in the presence of ATP-Mg. Chromaffin granules bound ${ }^{45} \mathrm{Ca}$ very rapidly and the binding was dependent on ATP-Mg. Neither ATP nor magnesium alone stimulated ${ }^{45} \mathrm{Ca}$ binding.

Most of the ${ }^{45} \mathrm{Ca}$ bound to the chromaffin granules was found in the stroma (chromaffin granule membrane fraction) and scarcely any ${ }^{45} \mathrm{Ca}$ was found in the soluble fraction of the granules (Fig. 1).

Next, the release of ${ }^{45} \mathrm{Ca}$ from ${ }^{45} \mathrm{Ca}$ preloaded granules was examined. Chromaffin granules were incubated with ${ }^{45} \mathrm{Ca}$ in the presence of $\mathrm{ATP}-\mathrm{Mg}$ and then collected by centrifugation and suspended in an ice-cold solution of $150 \mathrm{mM} \mathrm{KCl-40} \mathrm{mM} \mathrm{Tris} \mathrm{(pH} \mathrm{7.4)} \mathrm{con-}$ taining ATP-Mg. The suspension was incubated at $37^{\circ} \mathrm{C}$ with unlabeled calcium. Under these conditions, ${ }^{45} \mathrm{Ca}$ was released from the granules (Fig. 2) and the release of ${ }^{45} \mathrm{Ca}$ required the presence of $\mathrm{ATP}-\mathrm{Mg}$. These results show the exchange of environmental calcium with ${ }^{45} \mathrm{Ca}$ bound to the granule membrane.

\section{${ }^{45} \mathrm{Ca}$ binding to the granule and the release of catecholamine}

${ }^{45} \mathrm{Ca}$ binding and release of catecholamine were examined simultaneously. As shown in Fig. 3, release of catecholamine from the granules was observed in parallel with the binding of ${ }^{45} \mathrm{Ca}$ to the granules. 


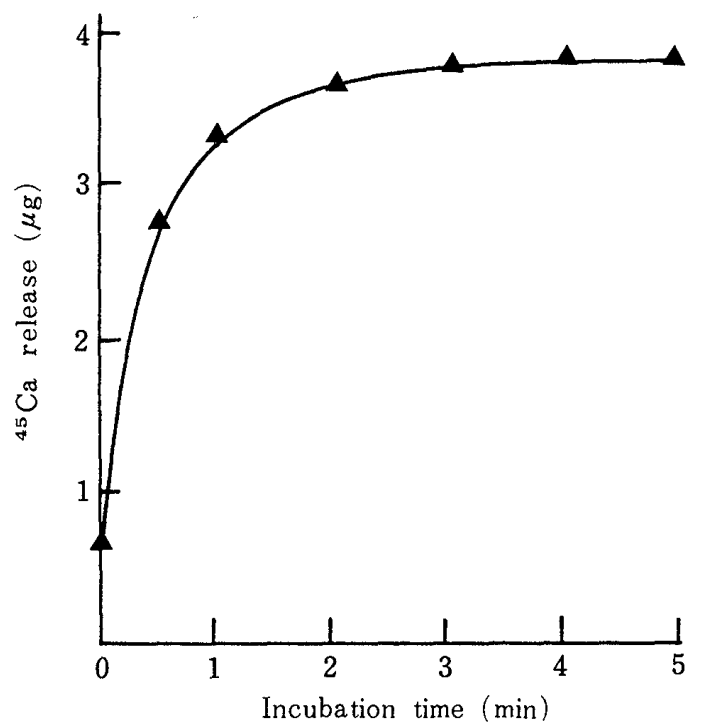

Fig. 2. Release of ${ }^{45} \mathrm{Ca}$ from ${ }^{45} \mathrm{Ca}$ preloaded granules.

Chromaffin granules ( $15 \mathrm{mg}$ of catecholamine) were incubated with ${ }^{45} \mathrm{Ca}$ (160 $\mu \mathrm{g}$ of ${ }^{45} \mathrm{Ca} / 40 \mathrm{ml}$ of mixture) in the standard incubation medium at $37^{\circ} \mathrm{C}$ for $5 \mathrm{~min}$. The granules were precipitated by centrifugation and incubated with unlabeled calcium. ${ }^{45} \mathrm{Ca}$ released into the medium was estimated. Each point means the average from five experiments.

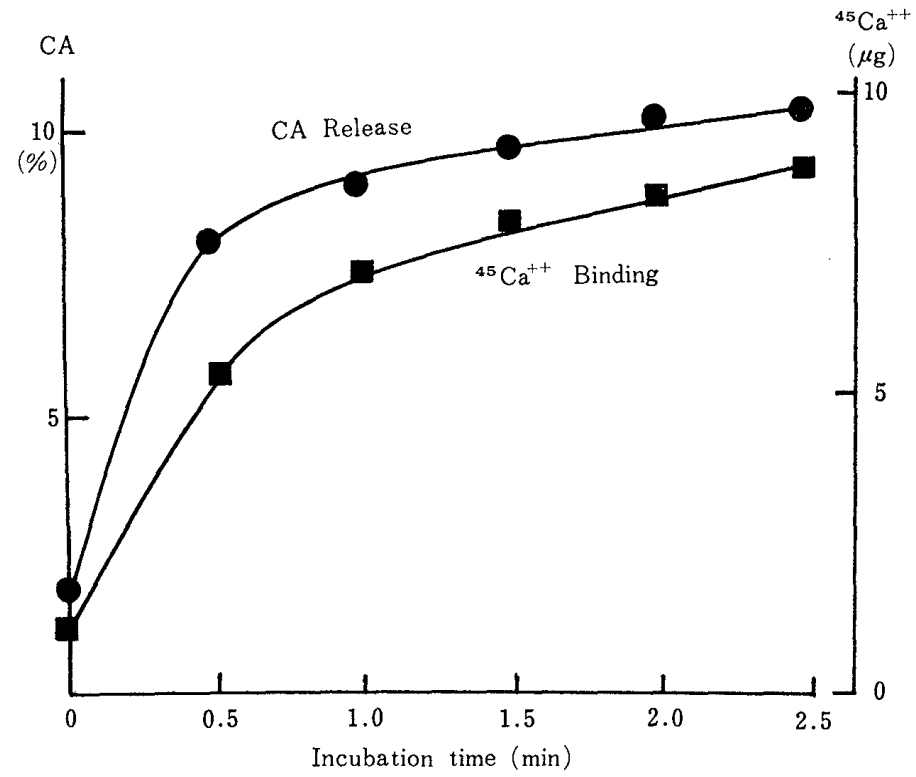

Fig. 3 . ATP-Mg dependent release of catecholamine $(\mathrm{CA})$ and ${ }^{45} \mathrm{Ca}$ binding to the granules.

Chromaffin granules (1500 $\mu \mathrm{g}$ of catecholamine) were incubated in a solution which consisted of $150 \mathrm{mM} \mathrm{KCl}, 40 \mathrm{mM}$ Tris ( $\mathrm{pH} \mathrm{7.4),} 4 \mathrm{mM} \mathrm{ATP}, 2 \mathrm{mM} \mathrm{MgSO}_{4}$ and 0.1 $\mathrm{mM}{ }^{45} \mathrm{Ca}\left(16 \mu \mathrm{g}\right.$ of ${ }^{45} \mathrm{Ca}$ in $4 \mathrm{ml}$ of incubation medium, $\left.2.2 \times 10^{4} \mathrm{dpm} / \mathrm{ml}\right)$. Incubation was carried out at $37^{\circ} \mathrm{C}$. Catecholamine released into the medium (expressed as $\%$ of total) and ${ }^{45} \mathrm{Ca}$ bound to the granules were estimated. 
Table 2. $\quad{ }^{45} \mathrm{Ca}$ binding and the release of catecholamine in various mediums Chromaffin granules were incubated with ${ }^{45} \mathrm{Ca}$ in the presence of ATP-Mg in various incubation mediums. Incubation was carried out at $37^{\circ} \mathrm{C}$ for $2 \mathrm{~min} .{ }^{45} \mathrm{Ca}$ bound to the granule and catecholamine released into the medium were estimated.

\begin{tabular}{lcc}
\hline \multicolumn{1}{c}{ Mediums } & ${ }^{45} \mathrm{Ca}$ binding & Catecholamine release \\
\hline $\mathrm{KCl}^{*}$ & $100^{\mathrm{a})}$ & $100^{\mathrm{b})}$ \\
$\mathrm{NaCl}^{*}$ & 89.6 & 104.0 \\
$\mathrm{LiCl}^{*}$ & 109.5 & 95.5 \\
$\mathrm{Choline}^{-} \mathrm{Cl}^{-} *$ & 97.2 & 146.0 \\
$\mathrm{NaBr}^{*}$ & 89.8 & 137.0 \\
$\mathrm{NaF}^{*}$ & 35.5 & 27.1 \\
$\mathrm{Na}^{*}$ itrate* & 25.3 & 31.0 \\
KSCN $^{*}$ & 1.1 & None \\
Sucrose** $^{*}$ & 32.0 & 37.9
\end{tabular}

$* 150 \mathrm{mM} \quad * * 0 . \overline{32} \mathrm{M}$

All values are expressed as the relative values to those in the $\mathrm{KCl}$ medium.

a) 34.2 nmoles ${ }^{45} \mathrm{Ca} / \mathrm{mg}$ protein $/ \mathrm{min}$.

b) $19.1 \mu \mathrm{g}$ of catecholamine released/min from granules containing $500 \mu \mathrm{g}$ of catecholamine.

\section{Effect of EGTA on the release of catecholamine and the calcium content of the granules}

As shown in Fig. 4, the release of catecholamine was inhibited by the addition of EGTA [Ethyleneglycol-bis-( $\beta$-aminoethyl ether)-N, $N, N^{\prime}, N^{\prime}$-tetraacetic acid]. On addition of EGTA, the calcium content of the granules decreased very rapidly whereas that of control granules without EGTA did not change. In another experiment, the effects of EGTA on the calcium contents of stromal and soluble content of granules were estimated. Results showed that EGTA caused a rapid decrease in the calcium of the stromal fraction but did not affect that of the soluble content (Fig. 5).

\section{Discussion}

Acetylcholine evokes catecholamine release from adrenal medullary cells and its action on the cell surface is to increase the permeability to calcium ions. There follows an increased movement of calcium down an electrochemical gradient to an intracellular site, and the consequence is the release of catecholamine. But the sequence of events between calcium influx and release of catecholamine has not been elucidated. In perfused adrenal glands, Borowitz (1969) observed an increased turnover of calcium ions in large granule fraction by stimulation with acetylcholine. Winkler et al. (1972) reported that mitochondria is the main site of calcium binding and that binding to chromaffin granules was much decreased. The main purpose of our experiment was to define the locus of calcium action and to know its correlate to catecholamine release.

${ }^{45} \mathrm{Ca}$ intruded into the cells showed a distribution similar to the endogenous calcium in the cells. Furthermore, ${ }^{45} \mathrm{Ca}$ incubated with the homogenate of adrenal medullary 


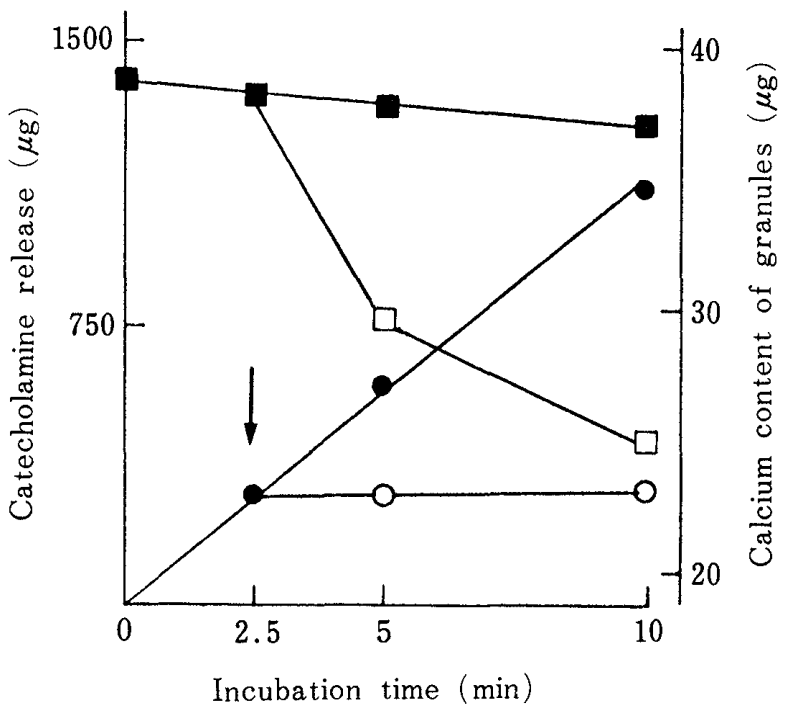

Fig. 4. Effect of EGTA on catecholamine release and calcium content of granules. Chromaffin granules ( $2800 \mu \mathrm{g}$ of catecholamine) were incubated at $37^{\circ} \mathrm{C}$ in standard incubation medium, in a final volume of $3.0 \mathrm{ml}$. After $2.5 \mathrm{~min}$ of incubation, $0.5 \mathrm{ml}$ of EGTA solution ( $35 \mathrm{mM}$ EGTA, $150 \mathrm{mM} \mathrm{KCl,} 40 \mathrm{mM}$ Tris, $4 \mathrm{mM}$ ATP and $2 \mathrm{mM}$ $\mathrm{MgSO}_{4}$ ) were added as indicated by the arrow. After incubation, the granules were sedimented by centrifugation and the calcium in the precipitate and catecholamine in the medium were estimated. Catecholamine in control (-) Catecholamine after EGTA (O-O), Calcium in control (1) Calcium after EGTA ( $\square-\square)$.

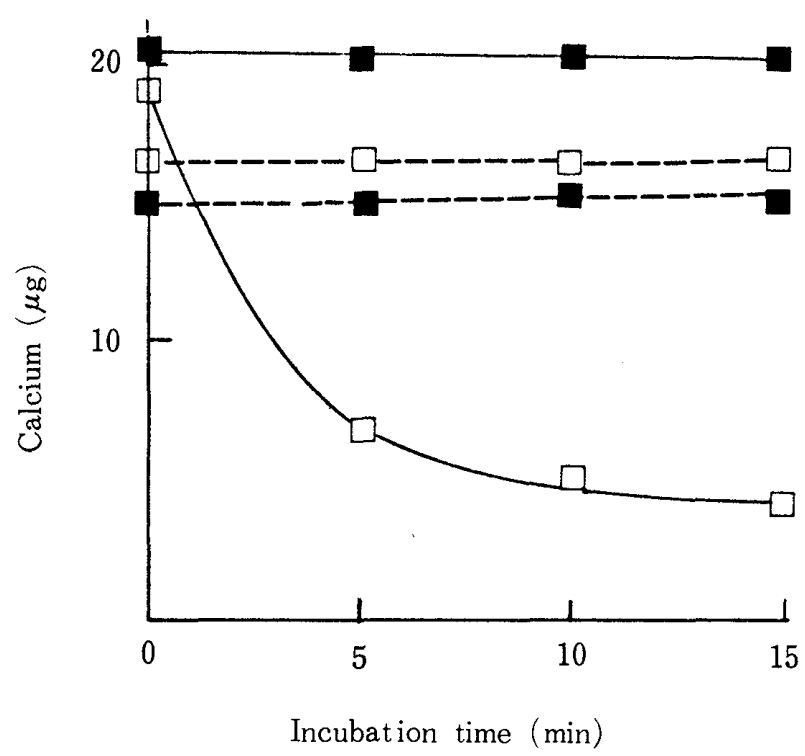

Fig. 5. Effect of EGTA on calcium content of granules.

Chromaffin granules ( $2800 \mu \mathrm{g}$ of catecholamine) were incubated at $37^{\circ} \mathrm{C}$ in the standard incubation mixture with or without $5 \mathrm{mM}$ EGTA. Subsequent procedures were the same as for Fig. 1. Stromal calcium (control - EGTA $\square-\square$ ), Soluble calcium (control

, EGTA $\square \cdots \cdots \square)$. 
cells also showed the same distribution. These findings how show that analysis of calcium movement in broken cell preparation provides accurate information on the dynamic movement of calcium in intact cells. In our experiment, the influxed ${ }^{45} \mathrm{Ca}$ was mainly recovered in particulate fraction and more than $70 \%$ of this calcium was found to be bound to chromaffin granules. Therefore, it is quite clear that chromaffin granules are the main calcium receptive site in the cells.

An interesting fact is that most of the calcium bound to the granules was confined to the stroma of the granules and incorporation into soluble content was much decreased. This is an important finding which was overlooked in previous reports. Kostron et el. (1977) reported that uptake of calcium by the granules was confined to the soluble content of granules. The discrepancy between these two findings arose from the difference in experimental procedures. He washed the ${ }^{45} \mathrm{Ca}$ loaded granule fraction with EDTA, which might remove major calcium bound to the granule surface, and yielded only the calcium incorporated into soluble content of granules. In our experiment, ${ }^{45} \mathrm{Ca}$ bound to the granule showed a rapid turnover with unlabeled calcium in the medium. It shows that calcium binding to the granule has a dynamic character and it will be easily trapped if EDTA was presented in the medium.

The next problem is the meaning of calcium binding to the granule membrane with special reference to catecholamine release from the granules. Binding of ${ }^{45} \mathrm{Ca}$ to the granules took place with a concomitant release of catecholamine. Both processes were dependent on the presence of ATP $-\mathrm{Mg}$ and temperature. Release of catecholamine was observed in the medium in which ${ }^{45} \mathrm{Ca}$ binding was stimulated by ATP-Mg. Thus, the state of granules induced by ATP-Mg favoring release of catecholamine also favors their binding of calcium. A question arises as to whether calcium binding to the granule is a requisite for release of catecholamine or changes of granule structure associated with the release of catecholamine provide a favorable situation for calium binding. Chromaffin granules have a heavy density and they sedimented in $1.8 \mathrm{M}$ sucrose. Changes of granule structure accompanied by the release of catecholamine causes the decrease in density, and such granules are not sedimented. In our experiment, more than $70 \%$ of ${ }^{45} \mathrm{Ca}$ bound to particulate fraction was recovered in the chromaffin granules which were sedimented in 1. $8 \mathrm{M}$ sucrose. This fact means that granules saturated with calcium still had a high density. Therefore, the binding of calcium to the granules was not directly linked to the release of catecholamine.

The ${ }^{45} \mathrm{Ca}$ taken up by the granules was mainly found to be bound to the stroma of the granules, with very little in the soluble fraction. Moreover, blockage of catecholamine release from the granules by EGTA was accompanied by loss of calcium from the stroma and not from the soluble fraction. These findings show that stromal calcium plays an important role in the release of catecholamine from the granules.

The transient increase in the free calcium concentration evoked by acetylcholine may trigger an increase of stromal calcium turnover and under this situation, the granules are brought to an activated, easily releasable state which would be the primary step in catecholamine secretion by exocytosis. 


\section{References}

Borowitz, J. L. (1969): Effect of acetylcholine on the subcellular distribution of ${ }^{45} \mathrm{Ca}$ in bovine adrenal medulla. Biochem. Pharmacol., 18: 715-723.

Douglas, W. W. \& Poisner, A. M. (1962): On the mode of action of acetylcholine in evoking adrenal medullary secretion; Increased uptake of calcium during the secretory response. J. Physiol., 162: 385-392.

Douglas, W. W. \& Rubin, R. P. (1961): Role of calcium in the secretory response of the adrenal medulla to acetylcholine. J. Physiol. , 159: 40-57.

Izumi, F., Oka, M. \& Kashimoto, T. (1971): Role of calcium for magnesium-activated adenosine triphosphatase activity and adenosine triphosphate-magnesium stimulated catecholamine release from adrenal medullary granules. Jap. J. Pharmacol., 21: 739-746.

Kostron, H., Winkler, H., Geissler, D. et al. (1977): Uptake of calcium by chromaffin granules in vitro. J. Neurochem., 28: 487-493.

Lowry, O. H., Rosebrough, N. J., Farr, A. L. et al. (1951): Protein measurement with Folin phenol reagents. J. Biol. Chem., 193: 265-275.

Oka, M., Izumi, F. \& Kashimoto, T. (1971): Calcium in the regulation of adenosine triphosphatemagnesium stimulated catecholamine release from adrenal medullary granules. Jap. J. Pharmacol., 21: 680-682.

Oka, M., Izumi, F. \& Kashimoto, T. (1972): Effects of cytoplasmic and microsomal fractions on ATP- $\mathrm{Mg}^{++}$stimulated catecholamine release from isolated adrenomedullary granules. Jap. J. Pharmacol., 22: 207-214.

Oka, M., Ohuchi, T. \& Yoshida, H. (1966): Isolation of catecholamine storage granules from adrenal medulla by the membrane filter technique. Life Sci., 5: 427-432.

Weil-Malherbe, H. (1952): The chemical estimation of adrenaline like substances in blood. Biochem. J. , 51: $311-318$.

Winkler, H., Schopf, J. A. L. \& Hörtonagl, H. (1972): Bovine adrenal medulla: Subcellular distribution of newly synthesised catecholamines, nucleotides and chromogranins. NaunynSchmiedebergs Arch. Exp. Path., 273: 43-61.

ウシ副腎髄質顆粒への $\mathrm{Ca}$ 結合と遊離：顆粒からのカテコールアミン遊離と $\mathrm{Ca}$

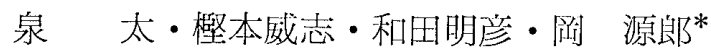

産業医科大学萖理学教室

*德忽大学突学部渠理学教坴

要 旨： 副督随質からのカテコールアミン遊離に於ける $\mathrm{Ca}^{++}$の作用部位と作用動態について、主 として分離したクロマフィン顆接を用いて解析をおこなった。アセチールコリン刺激によ り細胞内に流入した $\mathrm{Ca}^{++}$は特異的にクロマフィン顆粒に濃縮され、とりわけ顆粒膜に結 合して夕いだされた。この顆粘膜への $\mathrm{Ca}^{++}$結合と顆粓からのカテコールアミン遊離の間

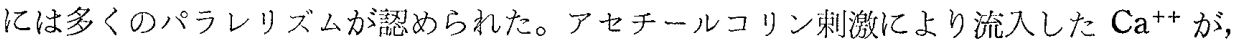
既に顆粒膜に大量に結合している内在性の $\mathrm{Ca}^{++}$と急速な装換反応を起こすことがカテコ ールアミン遊離の前提条件となること在明らかにした。 